\title{
Analysis of macro and micro nutrients in some Indian medicinal herbs grown in Jaunpur (u.p.) soil
}

\author{
Arun Kumar ${ }^{1}$, Ram Prakash Singh ${ }^{1}$, Narendra Pal Singh ${ }^{2^{\star}}$ \\ ${ }^{1}$ Department of Chemistry, Hindu P.G. College, Zamania Ghazipur, India; \\ ${ }^{2}$ Institute of Pharmacy, V.B.S. Purvanchal University, Jaunpur, India; ${ }^{*}$ Corresponding Author: arun.150476@gmail.com
}

Received 2 May, 2011; revised 30 May, 2011; accepted 7 June, 2011.

\begin{abstract}
Concept of trace elements being "the Inorganic Switches" has evolved during the last several decades. Ayurveda, the traditional Indian medicinal system also emphasises the importance of minor and trace elements in human health and disease. To evaluate elemental contents of some commonly used as health promoter and fever, 5 medicine herbs (stems) namely Guduchi, Vach, Mulahati, Joytishmati and Vidhara have been analyzed for four minor ( $\mathrm{Na}, \mathrm{K}, \mathrm{Mg}$ and $\mathrm{Ca}$ ) and eight trace elements $(\mathrm{Cr}, \mathrm{Mn}, \mathrm{Fe}, \mathrm{Co}, \mathrm{Ni}, \mathrm{Cu}$, $\mathrm{Zn}$ and $\mathrm{Cd}$ ) by atomic absorption spectrometry and flame photometry. Their accuracy was measured by replicate analyses. In general, elemental contents were found in varying amounts with large range. It is observed that many of medicinal herbs are enriched in one or more elements. Since these elements are bioavailable in natural form, probably in combination with organic constituents, these are likely to be easily assimilated by human bodies. Besides them, two toxic elements $\mathrm{Ni}$ and $\mathrm{Cd}$ were also found in insignificant amounts as these are likely to have originated from environmental contamination.
\end{abstract}

Keywords: Sample Used as Health Promoter and Fever; Medicinal Herbs in Jaunpur

\section{INTRODUCTION}

There are ample evidences of herbs being used in the treatment of diseases and for revitalising body system in almost all ancient civilizations [1-5]. Plants were the mainstay of many medicines having mystical and almost super natural healing power. There are many references to the curative properties of several herbs in the ancient

Indian literature, Rigveda, though a more detailed amount is found in the Atharvaveda from where Ay- urveda, the Indian traditional health care system (ayus $=$ life, veda = knowledge, meaning science of life) originated. Fairly compreshensive information about herbs has been recorded [6,7] in two treatises Charak Samhita and Shusruta Samhita - a base for Ayurvedic system of medicine. Looking to the importance of herbs, A Compendium of Indian Medicinal Plants in six volumes has been published [8]. Herbs play a significant role in modern times, when the damaging effects of food processing and over medication have assumed alarming proportions. These are now being increasingly used in cosmetics, foods as well as alternative medicine [9]. Besides lipids, proteins and carbohydrates required for human growth, supply of optimum quantities of inorganic micronutrients is also essential $[10,11]$. Several micronutrients such as $\mathrm{Cr}, \mathrm{Mn}, \mathrm{Fe}, \mathrm{Cu}$ and $\mathrm{Zn}$ etc., constitute a small fraction of our diet and play an important role in metabolic processes. Their excess or deficiency may disturb normal biochemical functions of the body [12]. Two main criteria considered for essentiality of elements are: first, its absence from diet results in departure from normal growth and metabolism; and second, the replacement of an element may suppress pathological symptoms. The composition of biological systems is so complex that the trace elements are totally masked by major constituents, and hence difficult to determine [13]. Some techniques, widely used in trace element analysis [14] are atomic absorption spectrophotometry (AAS), energy dispersive X-ray fluorescence [15] (EDXRF), electro thermal atomic absorption spectrometry [16] (ETAAS), inductively coupled plasma-atomic emission spectrometry (ICP-AES) and mass spectrometry [17] (ICP-MS). Each one of these has one's own advantages and limitations with regard to accuracy, precision, sensitivity and specificity. The advent of ICP-AES and ICP-MS all with multielement capabilities has slowed the AAS/AES market. However, AAS/AES technology is deeply entrenched in the field of analytical chemistry.

Several workers from different countries have reported the analysis of medicinal herbs of their respective 
countries. Lin et al. [18] detected 32 elements in 16 medicinal herbs by ICP-AES. Zhang et al. [19] employing ICP-AES for detecting major, minor and trace elements in 26 Chinese traditional drugs and compare their results with those obtained by AAS and NAA. Fan et al. [20] detected $\mathrm{Cu}, \mathrm{Fe}, \mathrm{Mn}, \mathrm{Zn}, \mathrm{Cr}, \mathrm{Mo}, \mathrm{Se}, \mathrm{B}, \mathrm{K}, \mathrm{Ca}, \mathrm{Mg}, \mathrm{F}^{-}$, $\mathrm{Cl}^{-}$in 13 diverse drugs by mean of AAS and HPLC methods. Shuping and Chen [21] detected $\mathrm{Zn}, \mathrm{Fe}, \mathrm{Cu}, \mathrm{Cr}$, $\mathrm{Co}, \mathrm{Ni}, \mathrm{Mo}, \mathrm{Sr}, \mathrm{Cd}$ and $\mathrm{Br}$ in seven medicinal herbs by employing ICP-AES. Yuan [22] detected 16 elements in 6 Traditional Chinese Medicines by AAS. Chen et al. [23] and Xu et al. [24] determined several elements in TCMs by AAS. Wang et al. [25] used ICP-MS for determined metal contents in several TCMs. Zhang [26] employed FAAS for determining $\mathrm{Zn}, \mathrm{Mn}$ and $\mathrm{Cu}$ in chinese medicinal herbs and drugs used in treatment of kidney diseases. Zhang et al. [27] determined 21 trace elements in 10 TCM samples by employing flame and graphite furnace AAS techniques. Chen et al. [28] determined $\mathrm{Ti}, \mathrm{Cu}, \mathrm{Mn}, \mathrm{Cr}$ and $\mathrm{Cd}$ in chinese medicines by using fluorination assisted electrothermal vaporisation ICP-AES. Liu et al. [29,30] determined $\mathrm{Co}, \mathrm{Mn}, \mathrm{Cu}$ and $\mathrm{Ni}$ in TCM and compare their results with those obtained by AAS and spectrophotometry. Dong[31] employed AAS for determining $\mathrm{Cu}, \mathrm{Cr}, \mathrm{Cd}, \mathrm{Pb}, \mathrm{As}, \mathrm{Sb}$ and $\mathrm{Sn}$ in donkey hide gelatin. Qiao et al. [32] determined 20 elements in TCM by employing XRF method. Yu and Mo employed extraction flame AAS for determining [33] Ge in TCM and foods. Hua et al. [34] determined Zn, Cd, $\mathrm{Na}$ and $\mathrm{K}$ in 11 kidney tonics based on TCM. Chuang et al. [35] used graphite furnace AAS for determining $\mathrm{Pb}$ and $\mathrm{Cd}$ in crude drugs. Lu et al. [36] determined As and $\mathrm{Pb}$ in TCM by spectrophotometric method. Jain et al. $[37,38]$ reported AAS and flame photometric determination of 19 elements in several medicinal plants. Saily et al. $[39,40]$ analyzed about 40 medicinal plants for 18 elements. It has been reported that $\mathrm{Na}, \mathrm{Mg}, \mathrm{Ca}, \mathrm{Cr}, \mathrm{Mn}$, $\mathrm{Fe}, \mathrm{Co}$ and $\mathrm{Zn}$ contents were common in many medicinal plants used for the treatment of asthama, rheumatism, diarrhoea etc. Further Sondhi et al. [41-43] have determined 20 elements in Ayurvedic bhasmas (medicine) used for the treatment of bronchitis, kidney and bladder disorder, skin diseases and Gonorrhoea by employing AAS, ICP- AES and flame photometer.

In the present study we have attempted to analyse specific parts of 5 herbal medicines which are often recommended as health promoter and fever. Nomenclature and uses of medicinal herbs analyzed in this study are listed in Table 1.

\section{EXPERMINTAL}

\subsection{Sampling}

All the medicinal herbs were procured from the local
Table 1. Some characteristics of herbal medicines analyzed in this study.

\begin{tabular}{|c|c|c|}
\hline NAME & $\begin{array}{l}\text { BOTANI- } \\
\text { CAL NAME }\end{array}$ & USES \\
\hline $\begin{array}{l}\text { GUDUCHI } \\
\text { GILOYA } \\
\text { (Stem) }\end{array}$ & $\begin{array}{l}\text { Tinospora } \\
\text { cordifolia }\end{array}$ & $\begin{array}{l}\text { Chronicfever, Jaundice, } \\
\text { Stomachincand digestive, milk } \\
\text { elleviation, splenomegaly, } \\
\text { Astringent, health promotive, } \\
\text { Rejuvenator }\end{array}$ \\
\hline VACH (Stem) & $\begin{array}{l}\text { Acorus } \\
\text { calamus }\end{array}$ & $\begin{array}{l}\text { Insanity Epilepsy, dry cough, } \\
\text { Diarrhoea, Pimples of Puberty, } \\
\text { Anti-neuralgic, sharp intellect and } \\
\text { sweet voice }\end{array}$ \\
\hline $\begin{array}{l}\text { MULAHATI } \\
\text { (Stem) }\end{array}$ & $\begin{array}{l}\text { Glycyrrhiza } \\
\text { glabra }\end{array}$ & $\begin{array}{l}\text { Hepatospleenomegaly, Injury, } \\
\text { Swelling, Rhumatism Gastric ulser, } \\
\text { Blood disorder, Bronchetis, Cough, } \\
\text { Asthama, Dysphonia, Fever, } \\
\text { Veneral diseases, T.B., Night fall, } \\
\text { Skin diseases, Stomachic }\end{array}$ \\
\hline $\begin{array}{l}\text { JOYTISHMATI } \\
\text { (Stem) }\end{array}$ & $\begin{array}{c}\text { Celastrus } \\
\text { panniculatus }\end{array}$ & $\begin{array}{l}\text { Brain tonic, Nervine tonic, } \\
\text { Analgesic Cardiac problem }\end{array}$ \\
\hline $\begin{array}{l}\text { VIDHARA } \\
\text { (Stem) }\end{array}$ & $\begin{array}{l}\text { Pueraria } \\
\text { tuberosadc }\end{array}$ & $\begin{array}{l}\text { Diuretic, Fever, Spleenomegaly, } \\
\text { Constipation Cardiac disorder, milk } \\
\text { alleviator, Skin deceases }\end{array}$ \\
\hline
\end{tabular}

market in Jaunpur (U.P.) cropped locally through dealers of herbal medicines. These were cleaned and then swiped to remove all the dust. These were further washed with distilled water and then afterwards swiped with tissue paper. The plant material was first dried in an oven and then dried under IR Lamp at temperature $<70^{\circ} \mathrm{C}$. The dried plant material was grounded to a fine powder (100 mesh) in an agate mortar. The powdered samples were stored in pre-cleaned polyethylene vials and handled with extreme care in a glove box to avoid contamination. Synthetic multielemental standards were prepared by spiking $2-5 \mu \mathrm{g}$ amounts of $\mathrm{Cr}, \mathrm{Mn}, \mathrm{Fe}, \mathrm{Co}, \mathrm{Ni}, \mathrm{Cu}, \mathrm{Zn}$, $\mathrm{Cd}, \mathrm{Ca}, \mathrm{Mg}, \mathrm{Na}$ and $\mathrm{K}$ in aqueous solution of their respective AR/high purity grade salts.

\subsection{AAS Measurements}

For the analysis of $\mathrm{Mg}, \mathrm{Ca}, \mathrm{Cr}, \mathrm{Mn}, \mathrm{Fe}, \mathrm{Co}, \mathrm{Ni}, \mathrm{Cu}$, $\mathrm{Zn}$ and $\mathrm{Cd}$ by AAS method, about $2 \mathrm{~g}$ of each sample were accurately weighed and digested in 5:1 mixture of nitric acid and perchloric acid [44]. After digestion, two to three drops of $\mathrm{HCl}$ was added and the solution was made up to $25 \mathrm{~mL}$., $\mathrm{Ca}, \mathrm{Cd}, \mathrm{Co}, \mathrm{Cr}, \mathrm{Cu}, \mathrm{Fe}, \mathrm{Mg}, \mathrm{Mn}, \mathrm{Ni}$ and $\mathrm{Zn}$ were determined by Atomic Absorption Spectrophotometer (GBC Avanta, Australia) using a mixture acetylene-air flame. The wavelength and senstivities for these elements were $422.7 \mathrm{~nm}$ and $4 \mu \mathrm{g} / \mathrm{g} ; 228.8 \mathrm{~nm}$ and $1.5 \mu \mathrm{g} / \mathrm{g}, 240.7 \mathrm{~nm}$ and $7 \mu \mathrm{g} / \mathrm{g} ; 357.9 \mathrm{~nm}$ and $4 \mu \mathrm{g} / \mathrm{g}$; $324.8 \mathrm{~nm}$ and $4 \mu \mathrm{g} / \mathrm{g} ; 248.3 \mathrm{~nm}$ and $5 \mu \mathrm{g} / \mathrm{g} ; 285.2 \mathrm{~nm}$ and $0.3 \mu \mathrm{g} / \mathrm{g} ; 279.5 \mathrm{~nm}$ and $2.5 \mu \mathrm{g} / \mathrm{g} ; 232.0 \mathrm{~nm}$ and 7.0 $\mu \mathrm{g} / \mathrm{g}$ and $213.9 \mathrm{~nm}$ and $1.0 \mu \mathrm{g} / \mathrm{g}$ respectively. The in- 
strument was precalibrated using high purity grade salts of respective elements.

\section{RESULTS AND DISCUSSION}

Elemental concentrations in 5 medicinal herbs (stems) were measured by relative method of AAS by using RMs and multielemental standards as comparators. Only if the values for elemental concentrations in RMs matched well within $\pm 10 \%$ of the certified values, the values for sample were considered. These are listed in Tables 2. Also included in the same tables are our data for participation in the analysis of dipleted Pine Needle (SRM 1575a). In each case triplicate analyses were made using $100 \mathrm{mg}$ each. It was observed that standard deviations for most elements were small suggesting a good precision. On the basis of good agreement, it is presumed that out values are listed in Tables $\mathbf{2}$ should be accurate and precise within $\pm 10 \%$. In order to compare the mean elemental concentrations of 5 medicinal herbs (stems) for $\mathrm{Na}, \mathrm{K}, \mathrm{Ca}, \mathrm{Mg}, \mathrm{Fe}, \mathrm{Cu}, \mathrm{Mn}, \mathrm{Cr}, \mathrm{Zn}$ and $\mathrm{Co}$ are plotted in Figure 1. The herbs of Jaunpur origin are found to contain some rare elements in amounts larger than other places.

A perusal of data in Table 2 shows that no single herb is enriched in all the elements. The electrolytic elements $\mathrm{Na}$ and $\mathrm{K}$ responsible for maintaining normal fluid balance inside and outside cells are generally found at minor and major concentration levels respectively. All the samples have shown much higher concentration of $\mathrm{K}$ by up to an order of magnitude compared to that of $\mathrm{Na}$.

The analysis of selected herbs leads to the following results:

1) Guduchi: The stem of this herb contains $\mathrm{Na}$ (0.120), K (0.50), Ca (16.0), $\mathrm{Mg}$ (3.1) in $\mathrm{mg} / \mathrm{g}$ and $\mathrm{Fe}$ (1300), Cr (2.5), Mn (130), Co (1.50), Cu (2.0), Zn (8.6), $\mathrm{Ni}(41)$ and $\mathrm{Cd}(1.3) \mu \mathrm{g} / \mathrm{g}$. Other plant organs were not analysed as they have negligible medicinal significance.

2) Vach: The stem of this herb contains $\mathrm{Na}(0.370), \mathrm{K}$ (2.50), $\mathrm{Ca}$ (11.0), $\mathrm{Mg}$ (5.7) in $\mathrm{mg} / \mathrm{g}$ and $\mathrm{Fe}(700), \mathrm{Cr}$ (2.5), Mn (100), Co (4.0), Cu (4.0), Zn (9.0), Ni (40) and $\mathrm{Cd}(0.4) \mu \mathrm{g} / \mathrm{g}$. Other plant organs were not analysed as they have negligible medicinal significance.

3) Mulahati: The stem of this herb contains $\mathrm{Na}$ (0.370), $\mathrm{K}(0.50), \mathrm{Ca}(15.6), \mathrm{Mg}$ (3.6) in $\mathrm{mg} / \mathrm{g}$ and $\mathrm{Fe}$ (3500), Cr (1.0), Mn (67), Co (4.20), Cu (1.0), Zn (8.6), $\mathrm{Ni}(26)$ and $\mathrm{Cd}(1.2) \mu \mathrm{g} / \mathrm{g}$. Other plant organs were not analysed as they have negligible medicinal significance.

4) Joytishmati: The stem of this herb contains $\mathrm{Na}$ (0.120), $\mathrm{K}$ (0.005), $\mathrm{Ca}(19.2), \mathrm{Mg}$ (4.1) in $\mathrm{mg} / \mathrm{g}$ and $\mathrm{Fe}$ (1750), Cr (4.0), Mn (13), Co (2.2), Cu (5.6), Zn (7.1), $\mathrm{Ni}(42)$ and $\mathrm{Cd}(0.4) \mu \mathrm{g} / \mathrm{g}$. Other plant organs were not analysed as they have negligible medicinal significance.

5) Vidhara: The stem of this herb contains $\mathrm{Na}(0.125)$,
Table 2. Elemental concentrations in stems of medicinal plants.

\begin{tabular}{|c|c|c|c|c|c|c|}
\hline Elements & $\begin{array}{l}\text { SRM Pine } \\
\text { Needle } \\
(1575 a)\end{array}$ & Vidhara & Mulahati & Vach & Guduchi & $\begin{array}{l}\text { Joyti- } \\
\text { shmati }\end{array}$ \\
\hline $\begin{array}{c}\mathrm{Na} \\
\mathrm{mg} / \mathrm{g}\end{array}$ & $\begin{array}{c}0.40 \\
-\end{array}$ & 0.125 & 0.370 & 0.370 & 0.120 & 0.120 \\
\hline $\begin{array}{c}\mathrm{K} \\
\mathrm{mg} / \mathrm{g}\end{array}$ & $\begin{array}{c}5.0 \\
(3.70 \pm 0.20)\end{array}$ & 0.05 & 0.50 & 2.50 & 0.50 & 0.005 \\
\hline $\begin{array}{c}\mathrm{Ca} \\
\mathrm{mg} / \mathrm{g}\end{array}$ & $\begin{array}{c}4.12 \\
(4.10 \pm 0.20)\end{array}$ & 14.4 & 15.6 & 11.0 & 16.0 & 19.2 \\
\hline $\begin{array}{c}\mathrm{Mg} \\
\mathrm{mg} / \mathrm{g}\end{array}$ & $\begin{array}{c}3.24 \\
-\end{array}$ & 4.0 & 3.6 & 5.7 & 2.1 & 4.1 \\
\hline $\begin{array}{l}\mathrm{Fe} \\
\mathrm{g} / \mathrm{g}\end{array}$ & $\begin{array}{c}210 \\
(200 \pm 10)\end{array}$ & 500 & 3500 & 700 & 1300 & 1750 \\
\hline $\begin{array}{l}\mathrm{Cr} \\
\mathrm{g} / \mathrm{g}\end{array}$ & $\begin{array}{c}3.2 \\
(3.0 \pm 0.3)\end{array}$ & 3.0 & 1.0 & 2.5 & 2.5 & 4.0 \\
\hline $\begin{array}{l}\mathrm{Mn} \\
\mathrm{g} / \mathrm{g}\end{array}$ & $\begin{array}{c}670 \\
(675 \pm 15)\end{array}$ & 16 & 67 & 100 & 130 & 13 \\
\hline $\begin{array}{l}\text { Co } \\
\mathrm{g} / \mathrm{g}\end{array}$ & $\begin{array}{c}0.10 \\
(0.10)\end{array}$ & 0.70 & 4.20 & 4.0 & 1.50 & 2.2 \\
\hline $\begin{array}{l}\mathrm{Cu} \\
\mathrm{g} / \mathrm{g}\end{array}$ & $\begin{array}{c}3.2 \\
(3.0 \pm 0.3)\end{array}$ & 2.0 & 1.0 & 4.0 & 2.0 & 5.6 \\
\hline $\begin{array}{l}\mathrm{Zn} \\
\mathrm{g} / \mathrm{g}\end{array}$ & - & 1.5 & 8.6 & 9.0 & 8.6 & 7.1 \\
\hline $\begin{array}{l}\mathrm{Ni} \\
\mathrm{g} / \mathrm{g}\end{array}$ & $\begin{array}{l}3.50 \\
(3.5)\end{array}$ & 27 & 26 & 40 & 41 & 42 \\
\hline $\begin{array}{l}\mathrm{Cd} \\
\mathrm{g} / \mathrm{g}\end{array}$ & $\begin{array}{c}0.50 \\
(<0.5)\end{array}$ & 0.8 & 1.2 & 0.4 & 1.3 & 0.4 \\
\hline
\end{tabular}

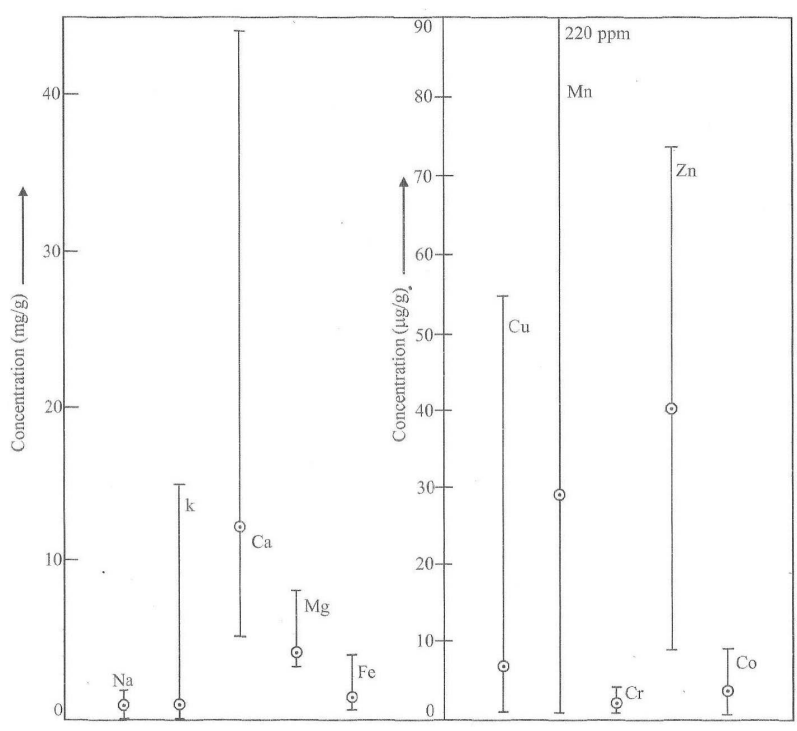

Figure 1. Comparison of elemental contents (range and median values) in medicinal herbs. Note: In Parenthesis are given certified values from literature.

$\mathrm{K}$ (0.05), $\mathrm{Ca}$ (14.4), $\mathrm{Mg}(4.0)$ in $\mathrm{mg} / \mathrm{g}$ and $\mathrm{Fe}$ (500), $\mathrm{Cr}$ (3.0), Mn (16), Co (0.70), Cu (2.0), Zn (1.5), Ni (27) and $\mathrm{Cd}(0.8) \mu \mathrm{g} / \mathrm{g}$. Other plant organs were not analysed as 
they have negligible medicinal significance.

Vach has highest contents of $\mathrm{Na}, \mathrm{K}, \mathrm{Mg}, \mathrm{Cr}, \mathrm{Co}, \mathrm{Cu}$ and $\mathrm{Zn}$. It has intellect promoting property and quite often used for removing pimples of puberty as it alleviates an sanity and epilepsy. Its organic constituents are a saryl aldehyde, acorin, caffeine and eugenol. Probably these elements may be associated with these organic constituents making them available in the bioavailable form. Yastimadhu commonly called Mulahati in Hindi has highest contents of $\mathrm{Na}, \mathrm{Ca}, \mathrm{Fe}, \mathrm{Mn}, \mathrm{Co}, \mathrm{Cu}$ and $\mathrm{Zn}$. This is sweet in taste and very often used in hyperacidity, peptic ulcer, anaemia, and cough. Its main constituents are glycyrrhizins and a glycoside called isoliqiritin. Joytishmati has very high contents of $\mathrm{Ca}, \mathrm{Fe}, \mathrm{Cu}$ and $\mathrm{Zn}$. It is quite useful as analgesic and cardiac problem. Guduchi has highest content of $\mathrm{Fe}, \mathrm{Mn}$ and $\mathrm{Zn}$. It is used in chronic fever, jaundice and milk elevation. Vidhra has very highest content of $\mathrm{Fe}, \mathrm{Ni}, \mathrm{Mn}$ and $\mathrm{Ca}$. It is quite useful in constipation, milk elevation and skin diseases. The accountability of different components for medicinal potency may be a search light for physicians [45] and dieticians $[46,47]$.

\section{CONCLUSIONS}

Five herbal medicines (stems) commonly used as health promoter and fever have been analyzed for 10 essential nutrients $(\mathrm{Na}, \mathrm{K}, \mathrm{Ca}, \mathrm{Mg}, \mathrm{Fe}, \mathrm{Cr}, \mathrm{Mn}, \mathrm{Co}, \mathrm{Cu}$ and $\mathrm{Zn}$ ) and 2 toxic elements (Ni and $\mathrm{Cd}$ ) by flame photometry and AAS. The elemental data should is reliable within $\pm 10 \%$. On the basis of elemental data in 5 medicinal herbs commonly used as health promoter and fever following conclusion may be drawn:

(1) Different parts of medicinal plants are enriched in some or other nutrient elements specially for $\mathrm{Ca}, \mathrm{Fe}, \mathrm{Mn}$, $\mathrm{Cu}$ and $\mathrm{Zn}$.

(2) No particular plant is enriched in all the elements.

(3) In general iron is enriched in all the medicinal herbs as there are used as brain tonics.

(4) Elemental contents of environmental contaminants are minimal so as not to cause any harm to our body system.

\section{ACKNOWLEDGEMENTS}

The first author(Arun kumar) grateful to Prof. G. Bhattacharjee, Head, Department of Chemistry, University of Roorkee, Roorkee for providing all the facilities during the course of this work. I am also thankful to all the faculty members of the Department of Chemistry for their timely suggestions and moral support. I would like to express my grateful thanks Prof. Indu Mehrotra, Environmental Engineering Section, Civil Engineering Department, University of Roorkee, Roorkee for permission to use their flame photometer and full co-operation during experimental work. I am also thankful to Prof. K. Chandra,
Director USIC and Mr. Juyal for their cooperation in analyzing some samples using their AAS. Computer library facilities extended by V.B.S. Purvanchal University, Jaunpur is thankfully acknowledged.

\section{REFERENCES}

[1] Sivarajan, V.V. and Balachandran, I. (1994) Ayurvedic drugs and their plant sources. Oxford and IBH Publishing Co. Pvt. Ltd., New Delhi.

[2] Zhou, J., Xie, G. and Yan, X. (2003) Traditional chinense medicines. Ashgate Publishing, Oxon.

[3] Steiner, R. P. (1986) Folk medicine: The art and the science. American Chemical Society, Washington.

[4] Kanias, G.D., Kilikoglou, V., Tsitsa, E., Loukis, A. and Radioanal, J. (1993) Nucl. Chem. 169, 483-491.

[5] El-Mekkawy, S., Meselhy, M.R., Kusumoto, I.T., Kadota, S., Hattori, M. and Namba, T. (1995) Chem. Pharmacol. Bull. 43, 641-648.

[6] Parchure, S.N. (1983) Charak samhita. Sagar Publications, Pune.

[7] Sharma, P.V. (1993) Dravya guna vigyan. Chaukhamba Bharati Academy, Varanasi.

[8] Rastogi, R.P., Mehrotra, B.N. (1998) Compendium of indian medicinal plants. Central Drug Research Institute/National Institute of Science Communication, Lucknow/New Delhi.

[9] Bakhru, H.K. (1998) Herbs that heal natural remedies for good health, orient paper backs. Division of Vision Book Pvt. Ltd., New Delhi.

[10] Prasad, A.S. (1993) Essential and toxic elements in human health and disease. Wiley-Liss, New York.

[11] 'O' Dell, B.L., Sunde, R.A. (1997) Handbook of nutritionally essential mineral elements. Marcel Dekker Inc., New York.

[12] Iyengar, G.V. (1989) Elemental analysis of biological systems - biomedical, environmental in: Compositional and Methodological Aspects of Trace Elements. CRC Press, Boca Raton.

[13] Seiler, H.G., Sigel, A., Sigel, H. (1994) Handbook on metals in clinical and analytical chemistry. Marcell Dekker Inc., New York.

[14] Herber, R.F.M. and Stoeppler M. (1994) Trace element analysis in biological specimens, Elsevier, New York.

[15] Daisy, J., Lal, M., Bajpai, H.N. and Mathur, P.K. (1999) J. Food Sci. Technol. 36, 264-265.

[16] Scancar, J., Milacic, R., Falnoga, I., Cemazar, M. and Bukovec, P. (2000) J. Pharm. Biomed. Anal. 22, 993-1002.

[17] Chan, Y.Y. (2003) S.C.L. Lo, J. Anal. At. Spectrom. 18, 146-150.

[18] Lin, S., Zhao L. and Yan, Y. (1991) Zhongguo Zhongyao Zazhi, 16222 [CA, 115 (1991) 35844 y].

[19] X. Zhang, Y. Duan and X. Wang, Fenxi Huazue, 19 (1991) 835 [CA, 116 (1992) 46449 v].

[20] X. Fan, Y. Chen, L. He, Q. hu, Y. Shi, C. Tian, C. Wang, S. Wang and Z. Yang Fenxi Shiyanshi, 12 (1993) 32 [CA, 121 (1994) $141814 \mathrm{x}]$.

[21] H. Shuping and L. Chen, Senxi Daxue Xuebao, 177 (1994) 56 [CA, 120 (1994) 331233 j].

[22] A. Yuan, Guangdong Weiliang Yuansukexue, 5 (1998) [CA, 130 (1999) 71676]. 
[23] X. Chen, S. Cao, P. Zhou, Y. Zheng, J. Huang, Zhongcaoyao, 29 (1998) 808 [CA, 130 (1999) 100786].

[24] X. Xu, G. Yen, G. Sun, X. Sun, L. Tian, S. Wang, Shizheu Daxue Xuebao Ziran Kexueban, 2 (1998) 43 [CA, 130 (1999) 187292 q].

[25] X. Wang, Z. Zhuang, D. Sun, J. hong, X. Wu, F. Lee, M. Yang and H.W. Leung, At. Spectro, 20 (1999) 86 [CA, 131 (1999) $78563 \mathrm{~d}]$.

[26] T. Zhang, Zhongguo Yiyuan. Yaoxue Zazhi, 19 (1999) 345 [CA, 131 (1999) 106913 p].

[27] Q.F. Zhang, S.S. Peng, N. Ni, X.Y. Hu and W.Y. Yang, Guangpuxue Yu Gungpu Fenxi, 19 (1999) 203 [AA, 61 (1999) 9G194].

[28] S.Z. Chen, F. Li, Z.H. Liao, T.Y. Peng and Z.C. Jiang, Fresenius J. Anal. Chem., 364 (1999) 556 [AA, 62 (2000) IF29].

[29] L. Liu, G.D. Shao and T.Z. Zhou, Fenxi Shiyanshi, 14 (1995), [AA, 56 (1996) 46135].

[30] L. Liu, M.Y. Wang and J.H. Lei, Fenxi Ceshi Xaebao, 18 (1999) 59 [AA, 62 (2000) 4G233].

[31] S.L. Dong, Guangpuxue Yu Guangpu Fenxi, 16 (1996) 91 [AA, 59 (1997) 7G115].

[32] Y.J. Qiao, S.J. Wang and K. Su, Guangpuxue Yu Guangpu Fenxi, 16 (1996) 108 [AA, 59 (1997) 6G132].

[33] M.Y. Yu and S.J. Mo, Guangpuxue Yu Guangpu Fenxi, 16 (1996) 93 [AA, 59 (1997) 1G97].

[34] R.N. Hua, Z.G. Zhu, W.M. Liu and J.T. Liu, Guangpuxue Yu Guangpu Fenxi, 19 (1999) 866 [aa, 62 (2000) 5G188].

[35] I.C. Chung, Y.L. Huang and T.H. Lin, Anal. Sci., 15 (1999) 1133 [CA, 132 (2000) 69424c].
[36] Y.Y. Lu, G.J. Wu, Y.H. Wu and Y. Yuan, Guangdong Gongye Daxue Xuebao, 16 (1999) 106 [CA, 132 (2000) 17125f].

[37] Jain, N., Shahoo R.K. and Sondhi, S.M. (1992) Indian Drugs, 29,187.

[38] N. Jain, A. Magan and S.M. Sondhi, Indian Drugs, 30 (1993) 190 [CA, 119 (1993) 125359f].

[39] A. Saily, R. Sahu, D. Mohan, B. Gupta and S.M. Sondhi, Indian J. Phara. Sci., 56 (1994) 186 [CA, 125 (1995) 18092z].

[40] A. Saily, R. Sahu, B. Gupta and S.M. Sondhi, Hamdard, 37 (1994) 18

[41] S.M. Sondhi and G.K. Janani, Indian Drugs, 32 (1995) 125 [CA, 123 (1995) 123327c].

[42] S.M. Sondhi and N. Agarwal, Hamdard Medicus, 38 (1995) 24.

[43] S.M. Sondhi, V.K. Sharma and R.P. Verma, Indian Drugs, 33 (1995) 67.

[44] J. Zhang, Fenxi Kexue Xu Ekao 16 (2000) 55-57.

[45] Singh N.P. et al. (2004) Proceeding of Nat. Seminar on Environment Degradation and Conservation, Kutter P.G. College Chakkey, New Delhi, 17-18 December 2004.

[46] Singh N.P. et al. (2004) Biochemical aspects of anticonvulsant drugs, Environmental Scarcity and Side effects, Proceeding Nat. Seminar on Environment degradation and conservation, Kutter P.G. College Chakkey, New Delhi, 17-18 December 2004.

[47] Singh N.P. et al. (2009) Medicinal plants: A powerful health Aid, Proceeding $18^{\text {th }}$ Annual Conf. Purvanchal Academy of Sciences, 19-20 Feburary 2009. 